\title{
The Study of Ahmad Jam's Verbal Thoughts
}

\section{El estudio de los pensamientos verbales de Ahmad Jam}

\author{
Karomatullo Olimov \\ Academy of science of the Republic of Tajikistan \\ ORCID ID: https://orcid.org/0000-0001-6175-9959 \\ Saeid Yoosefisoorany \\ Doctorate philosophy, academy of sciences of the republic of Tajikistan \\ ORCID ID: https://orcid.org/0000-0002-2820-182X
}

*Correspondence

Email: olimovk_2007@mail.ru

\section{Cite as:}

Olimov, K., \& Yoosefisoorany, s. (2021). The Study of Ahmad Jam's Verbal Thoughts. Propósitos y Representaciones, 9 (SPE3), e1116. Doi:

http://dx.doi.org.10.20511.pyr2021.v9nSPE3.1116 


\section{Summary}

Ahmad Jami is a well-known mystical figure, and his mystical roots are often discussed. But there has been no independent research into his verbal thoughts yet. An important question that has been discussed in this regard is what elements and components of Ahmad Jam's verbal thoughts contain? The present article is a descriptive-analytical one and uses the library method to investigate the mentioned question. The results of the study indicate that wisdom, Genesis, Step, Judgment, and magnitude, the vision of God at the resurrection is one of the most important theological components of Ahmad Jam. The results of this study indicate that the influence of theological issues in Ahmad Jam's thought is so much that his works without knowledge of his theological views will be incomplete.

Keywords: Ahmad Jam, Verbal Thought, Reason, incidence and obsolescence, Judgment and destiny, God's vision of the resurrection

\section{Resumen}

Ahmad Jami es una figura mística muy conocida, y a menudo se discuten sus raíces místicas. Pero aún no se ha realizado una investigación independiente sobre sus pensamientos verbales. Una cuestión importante que se ha discutido a este respecto es ¿qué elementos y componentes de los pensamientos verbales de Ahmad Jam contienen? El presente artículo es de tipo descriptivoanalítico y utiliza el método de biblioteca para investigar la cuestión mencionada. Los resultados del estudio indican que la sabiduría, Génesis, Paso, Juicio y magnitud, la visión de Dios en la resurrección es uno de los componentes teológicos más importantes de Ahmad Jam. Los resultados de este estudio indican que la influencia de las cuestiones teológicas en el pensamiento de Ahmad Jam es tanta que sus obras sin el conocimiento de sus puntos de vista teológicos serán incompletas.

Palabras clave: Ahmad Jam, Pensamiento verbal, Razón, incidencia y obsolescencia, Juicio y destino, La visión de Dios de la resurrección

\section{Introduction}

Ahmad Jam is a pure institution sufi that hasn't been regarded as he deserves. Right now, there is nothing new except valuable research by Ali Fazel. So this article can partially illuminate some of his verbal thoughts. Abu Naser Ahmad Ibn Abi Al Hassan Ibn Ahmad Bin Muhammad Bin Jarir Bin Abd Allah Al-Jith Al-Manali Al-Manaqi in Maharram Al-Haram month was born in Namegh (Name) one of the Seljuk era villages of Khorasan province (today this area is still well known and one of the Kashmir areas). in the age of the Seljuks (Fazel, 1999: 17). His descendants were known as the Yemeni Arabs and the descendants of Jirayr bin Abdullah Bajli Sahabi. Ahmad Jami spent his youth in debauch and slurp until the year (462 AH), after that, he had a development in emotional excitement with the help of a heavenly ball and a spiritual strobe. This change made him determined to contemplate his dark past that led to his repentance. After that, he preached the listeners and readers Under his influence to led them to repentance. In his last years of life, after returning from the pilgrimage to the house of God, on 10th of Muharram, in his own house, he passed away.

Sheikh Ahmad Jami is one of the first people in the field of mysticism and Sufism to take a step in this direction and with his vocal and effective speeches on the topics of Iranian and Islamic Sufi mysticism, has precious and valuable works commemorated and it is always boiling over for generations to come, a boasting tool for true officials to the fullest extent and authority. Sheikh's work is one of the earliest works on mystical subjects that fortunately survived the days of the times and is still shining at the peak of Iranian noble works. Much research has been done on the mystical thoughts of Ahmad Jami, but no research has been done on his verbal thoughts. Ahmad Jami is generally regarded as a mystic with mystical thoughts However, his verbal ideas have been neglected and this has made the present 
research a necessity. Based on what was said, the basic question that is being addressed in this article is, what points does Ahmad Jami's verbal ideas contain? The present article seeks to investigate and answer the question raised.

\section{Reason}

Contrary to the notion of some who have considered Sufism to be among the dissidents and scholars of reason and have written to substantiate their claim: Another sin is the enemy of the Sufis who have shown "wisdom". Wisdom is the most precious data of God and everyone should know it and guide it in their deeds, because they have been ignorant of their deeds, have shown enmity with them, and have opened their mouths to reproach:

Love came His mind was displaced morning came and his candle became poor

"Sheikh, if a Darwish asked us a question what should be our reflect?" "mind is a tool to servile" Sheikh said "you can't find the secret to lordship which he is the teller and the teller has no trace in the past (Kasravi, 1323:22).

But Ahmad Jam believes that "the first thing God created is wisdom, and the first thing that came out of the supreme was the transcendence of wisdom". (Jam, Bita, $1^{\text {st }}$ book:21; Jam 1387: 49) And its power, it sees as deterring malicious practices. He, like Mostamali Bokhari believed in the wisdom, reason, and guidance of many (Mostamali Bokhari, 1366: 49). And it introduces it as a complement to religion and the Shari'ah, so it is called "Sepah Salar", and along with the guidance and science of light, one of the four things that it considers a necessary condition for entering Islam and knowing it. "The mind is a simple substance that realizes things with their righteousness" says The wises (JamzhendePil) 1343:138). And without it the Muslim warns against the Word of God in the veil of monotheism and theology and knowledge of the attributes of transcendence, as he writes. But if these four things are not a helping hand, it will not be rounded up to a Muslim burden. (Jam 1387: 94) In the fourth chapter of the first chapter of the book Bahar al-Haqiqah, he discusses the value of "knowledge" and writes: "Truth should be known that there is nothing beyond knowledge" (Jamzhendepil), 1343: 59). He then introduces the subject of knowledge to the people of knowledge and introduces the summary and abstract of the Prophet Muhammad (PBUH). He goes on to speak of the creation of reason and points out that God has inculcated the light of poverty, knowledge and guidance in the light of reason. (Jam(zhendepil) pefore, p59) And then writes about its importance: "Then he said, to my dignity and glory that I have not created any creature dearer than you. Let me sing to you and take you and let me know you". (Jam(zhendepil), before, p59). If we were asked to compare the position of reason with the Shari'a and the religion, we would consider Ahmad to represent the reason in a lower position than the religion and the Shari'a, and even as theologians, as he writes: "And it was not the Prophet (pbuh) from the intellect, but all the head of the Prophet (pbuh) came from the light of Muhammad Mustafa (pbuh); and that light is the light of knowledge, not the light of reason; because if it was the light of reason it would shine anywhere so then in this case wise men quote: The Almighty saying: Those are the evil of the wilderness (Jam, 1387: 50). or in other places he says: "it's been written God created was mind, but know that no creations became preceded before Mohamad (pbuh). (Jam pishin, 2005, p 102).

The important point about Ahmad Jam's belief in reason is that he considers the power of reason to be in need of guidance and guidance from the unseen and the God's will world. Because, in his view, "the reason for this is that if you knew the intellect and you knew the wise, you would come to know wherever the reason was. So it is a few thousands of wise men who have no knowledge of God to know, that their intellect informs all creatures and does not regard God as deaf and ignorant, and many of these lowly minds know God so many that the name of Khwaja Emami is the one, they know!" (Jamzhendepil) 1343:59). In his view, the tool for understanding the reason is through senescing the sensory organs (which also make the human sensory organs weak and in many cases mistaken in understanding the world around us) so that if the intellect does not guide the divine science it will not guide the intellect it also misleads people (Jam, 2008: 96). 


\section{Obsolescence and Genesis}

Ahmad Jam, writes: "However in the understanding of wisdom and knowledge there can be no creature that has always been a supreme God, and never has been a no one else that he was, and always is impeccable (Jam, Pishin, p79). " So, in his view, he is only the ancient God, and everything other than God is referred to as the "world" or "beyond world"' Whether in matter and form, or in persons or in all kinds, in parts and in whole, and in matter and in substance, all are the events, "God is eighteen thousand and one, for he always was, and always will, and never was, never be. And if all the creatures of mankind, demons, possessions, and all of the spirits of the spirits, and of all creatures, each and every one so much as science, intellect, intelligence, understanding, and preservation, that no creature can be understood and illuminated». As for his soul, like al-Ghazali, he believes that the spirit is an accident and that the believers believe that their soul is out of Islam's circle (Ghazali tousi, 2005: 17). " The people who say: Ghosts are old, stay away!' Do not believe in this promise that is neither the path of Islam nor the path of Muslims!" (Seraj Tousi, 2003: 200). He puts it this way with the Qur'an: "And other people have said that it will be the worship of spirits. He puts it this way using the Qur'an: "And other people have said that it will be the worship of spirits". It is also not based on any principle, for it affirms God says in his holy book: "But does he not know that when the contents of the graves are scattered" which means "Take out the graves from the dead". And it is certain that the soul is not dead, and is not in the grave; then the promise that it shall be the souls of the spirits, if thou wilt accept the promise of God, and whosoever shall promise it, know it, and what it is (Jam, Pishin, p 300).

Ghazali, who introduces that the soul is within the heart, writes about its subject: "So those who thought that the old soul was wrong, And those who said that it was Presentation they also did wrong, Presentation was not the stand itself, And it was consequence, and life is The humanistic principle, And all of that is his form, how was Presentation, And those who said that the body was false also did so, That body was divisible, And John is not divisible, But there is another thing they call the soul, And it is divisible, but it also has the spirit of war, but this spirit, which we call "heart", is The place of excellence God's knowledge, And this is not my life, And this is neither body nor Presentation, but is the gemstone of essence of angels, And the truth is difficult to know" (Ghazali Tousi, Pishin p17).

\section{Predestination}

In the subject of Predestination Ahmad Jami believes one's destiny is predetermined from the beginning and he writes: "The Almighty says: "And God does what He wills," and "He rules what He wants." It was not you on the day when we were judged and honored. We did as we wanted, and there was no desire in it. Let us do what we want today, and no desire at all. Tomorrow will be the same, as we have known! No one is upset about it, and no one is right and no wrong" (Jam, 1343: 52-50; Jam, 2008: 67; Jam, Pishin, p232). But this determination is incompatible with the will of man, and man is free because God has determined man's destiny based on man's own choice, and humans are free in their own actions. They can act and they can't not too"

Fate has two meanings in which two can be said to be fateful, and as Ahmad Jam's work reveals, he has referred to fate in both its meaning in his works.

1. Scientific fate " "from the very beginning on the ancient science, And on eternal wisdom, And ironically, and fate, and Providence, And old-fashioned devotion has done something that not one bit be lost or moved, And he will not be overwhelmed by the amount of mosquitoes that benefit him, which is not his old science (Jam 2008: 144; Jam,

\footnotetext{
${ }^{1}$ It means measuring. The scientific destiny of God is: God knows how anything can happen at any time and any place. In other words, the scientific destiny of God is the knowledge of God to provide the premises and the conditions for the occurrence and subsequent occurrence of phenomena. This scientific destiny of God has no contradiction with man's authority, for God knows what actions and actions one performs by His own choice and choice. In fact, the previous divine science has no disagreement with human knowledge, since human action is, in spite of being voluntary, owned by the science of God, and such science not only has disagreements but also emphasizes it.
} 
Bita: 262; Jam 1387:33). This kind of fate is not at odds with the human being but in its during and confirmation, which is further explained in the footnote.

2. Objective fate "think in the holy words as mighty God says: We divided them among their subsistence in this world. Which says we divided between you the Subsistence of this world, we surcharged on each of you: so no one will be able to change our path. Although all creatures provide the first and the last for one task and one thing, they will not be able to more or less overtake our part. If our brothers heed the advice of their brother, and do not despise the proud pride of the devil, and the deceitful people of the world, to be superior to them (Jam 2008: 25; Jam, 1343:145).

This destiny is also incompatible with human's will because our will, authority, and precepts of our voluntary actions, like all other phenomena, come from a particular conduit and its own distinct circle ${ }^{3}$. However, the things God has ordinarily destined to do are all algebraic, and man has no power to change them, as Ahmad Jam writes: "Perhaps the brave men, and the brave men, who sought to change this part, failed" (Jam, 1387:26-27-28). Therefore, there is no place for the will and the illusion of human's will, our organs were given to us by force and the Almighty God, with His own objective fate, specifies the cadre for the life of every person that the voluntary activity - which we are also given by compulsion - is carried out within it. We are free within this framework to do whatever we want, but outside, it is out of our control. At the end to sum up Ahmad Jam writes: whoever is not satisfied with the part God gave them, they have an odor of disbelief (Jam, Pishin, p25).

Fate means to finish and complete the task and it can also be called the final step of a task. Like fate judiciary, has two terms: "scientific judgment" and "objective judgment". knowing the end of the work and the final stage of an act is "scientific judgment", "If no one came to the judgment of God, and if he could escape his judgment, you would be second to it" (Jam, Pishin, p 147; Jam 1343:50).

Finishing, and finalizing a work is called "objective judgment." In two people gaining knowledge and a master, if one does wrong the other will do the same. God will make one of them the master of the world and the other so small, he'll remove one from great power down to begging and picking clusters, and take one from picking clusters up to ruling and power!”

God's scientific judgment, is the knowledge of God about the inevitability of phenomena. This scientific premise of God is not incompatible with human's will because God knows that a phenomenon or action will certainly occur with human's will. In other words, God's scientific judgment for the voluntary actions of man is, God knows that such a human action will certainly occur even though it is voluntary.

God's objective judgment means, The attribution of the realization of these phenomena to God. In other words, it is the divine purpose of God to know the existence of phenomena from the beginning of creation to the period of prosperity and end of life, but also from the provision of the preparations made under divine wisdom and the preparation of the conditions for its emergence and finalization Count at his will. Thirdly: 1- The attainment of any cause to the extent necessary for existence by the fulfillment of its full cause, 2- No creature has independence in existence and in the works of existence, 3- Of course, the necessity of existence of all phenomena will be documented by God Almighty, who has absolute richness and independence.

Ahmad Jam's quotes a poem of Ferdowsi in this particular:

What a world he made himself the creator has done it by its own

(Jam, Seraj-Al-Saeerin, p277).

\footnotetext{
${ }^{2}$ That is to say, to size up, to make something to size, or to size to something. The objective destiny of God is to design the creatures in such a way as to bring about specific phenomena and effects, and this will naturally be different in terms of the approach and dimension of each phenomenon as it relates to sex, type, person, and individual states. It will also be different. For example, the destiny of the human species is to live on earth from a specific time to a certain excellence, and the destiny of every person is to be born to a specific parent and for a limited period of time, as well as to the daily destiny and other voluntary actions and actions. It is about providing specific conditions for each of them. In fact, God's objective fate, that is, God creates every creature with its own limits, sizes, conditions, characteristics, and abilities.

${ }^{3}$ For example, human speech, which is an optional act, must come from its own conduit or conduit, so God has given this conduit for the realization that a human being has a limb, larynx, vocal cords, tongue, teeth and lips ... Optional action is possible. Also, the prepositions of the voluntary verbs are also ordained by God with special conditions, such as eating, which God has provided and created materials to be seized, so that man could be seized so that man could be seized, if not members Eating - which is an optional verb - would not take place until it took over foreign matter.
} 
In fact, objective judgment of God requires this fact that - just as the existence of any phenomena is attributed to the permissive will of God and without it there is no creature to come into existence - so does the emergence of anything documented in the judiciary- It is divine in nature and without it, no creature will find its own form and boundary and will not reach its end. Ahmad Jam considers the root of greed in world's do, the lack of faith in divine predestination as he writes: The greed of the world's do falls from uncertainty into the greed of the world, and whichever He wanted survived the greed of the world (Jam, Pishin, p 276).

According to the foregoing, divine destiny does not conflict with human will, and human will is in the will of God, not beyond what is important, although man was not the subject of his own voluntary acts, but the subject of the absolute It is the length and power of God. Therefore, whatever one does, because according to their active interpretation God, must also use words such as (Inshaallah) God willing and so on, which this is exactly verbal monotheistic. And whatever anyone asks me to do tomorrow, or after tomorrow, or another month, or another year, and does not say 'God willing' or 'If God wills', that is his intention of sin. Because the helpers of the poor, whether good or evil, whatever they be full of sin, and some have said to be the great sin (Jam, Pishin, p287;Jam 1387:43; Jam 1343:52).

However, it is this man who must be content with his status of being the Lord of the Worlds by divine will and desperately submit to the divine. "And science, and fate, and the wisdom of God and sublimity of that engineering, and if you were to make silk out of it, or if make a robe black and white, and if red and white. The engineer will be destroyed somewhere, or in the desert, where he will settle, or he will do fencing, or a fence, or a castle, or a courtyard; Still he sees it as it will be, and knows what it will be like" (Jam, 1387: 144; Jam 1387:145; Jam 1343: 243; Jam, 1387: 89; Jam, Bita, 244).

\section{Seeing God in the resurrection}

About seeing God in the resurrection by believers "Ashaere"," Motazele" and "Shia'a" has their own specific point of view. Ahmad Jam, a Hanafi Sunni who is very similar to the Ashaere in his words. He believes in the sight of God in the resurrection and writes: "The sight of God in the resurrection is the right of a believer" (Mostamali Bokhari, Pishin, p373). So he reasons using the Prophet's (pbuh) words that God is seen at the resurrection, as the moon is seen at the fourteenth nights, and as the sun is seen when there is no cloud in front of it, the believers see God and the disbelievers do not see God. "The sixth rule is to confess that the God can be seen supernaturally, and believers from Paradise would see God with their own eyes Undoubtedly, he will not have face, color, board and quality, but see undoubtedly, as you know undoubtedly today, It is not the same as anything and is the hearer of sight but look as God has informed: "The faces of [that day] appeared to him as his Lord, his overseer" (Jam, 1387: 91). He introduces the reward of knowledge and recognition is seeing God in the resurrection, as he writes: "Knowledge and the Light of Knowledge of the Throne and Seat, and of the Tablet and Pen, and of Jen and Onas, of Angel and Sky, of seas and deserts - and of all that is and has been created by the dear God, the Light of Knowledge is vainest; All his prestige is that he is worth the price" (Jam,1343, 162).

\section{Conclusion}

If we go into the history of humanity, we will find that this planet was the birthplace of human beings who have made profound changes to humanity through their thoughtful presentation. One of them is Ahmad Jam, who has so far paid little attention to his ethical, mystical and

\footnotetext{
${ }^{4}$ Ashaere Commentary on God's Vision: According to the verse of Sharif: "All aspects of the past are observable," the faces on that day are lively and joyful and look to its Lord. They believe in God, but that does not mean that God has a body. Because they explicitly say: God's vision does not mean his body and body.

${ }^{5}$ The Mutazele view of the sight of God: Eyes do not belong to God and do not see and understand God because God is visible so that the eyes can see things in a direction that is shaped and colored and God This is one of them, but God sees everyone and everything ${ }^{6}$ Shia'a view of the sight of God: Apart from verses that prove that the sight of God is impossible, such as the verses: "Anam, 103; Arafah, 143; Nisaa, 153; To see and be seen is to be an object, to have a place, to have, and to possess. And besides, it requires visualization, its limitation, its orientation, and all this are impossible in the sight of God, and it is rejected by the wisdom of the Qur'an.
} 
philosophical ideas, which makes him unrecognizable in Some of the important books of the Iranian mystics and intellectuals have been published so the present treatise introduces his thoughts and ideas. Ahmad Jam, is a social thinker and a pious Sufi, is a man of freedom and a free-spirited man with a Shari'a-oriented moral and philosophical mindset who advocates shari'abased mysticism as a way to cure society of moral and Social illnesses and diseases. He advocates for the establishment of justice in the community and the unity of the people who, in a pure spirit, free from any religious prejudice, has placed the principle of peace and reconciliation with the followers of all religions. In his eyes Zartoshtian, Christian, Jews, idolaters and Muslims, are the same and writes: "Obedient is dear wherever he is, weather between Zartoshtians, Jews or Christians, and a sinner is a sinner wherever he is even If he's in God's house ". He spent most of his life awakening the audience and in the fight against ignorance and Sufism, the worshipers and the mystics of his century. He endured a lot of suffering in his high and low life, lived in the 5th century and, like his contemporaries, chose a particular mystic, so his mysticism with the mysticism of Abolhassan Kharqani, who eschewed the mantle of creation and had chosen to be isolated, had a great difference. And it also differs from the mysticism of Sheikh Abu Sa'id Abu al-Khair - despite the similarities - being one of the most extreme mystics in the discussion of unity, and it also differs from the mysticism of Baba Taher's naked heart and lover. And with Ahmad Ghazali who owns the book of Sufism and Imam Qashiri from moderate mysticism, even with Abu Hammad Imam Mohammad Ghazali who is a Sufi Muslim, in general has many similarities with the mysticism of Ahmad Jam but still a significant difference between them can be seen. And as a result of his open-mindedness and the creation of a new system of worship and his diligent effort to coordinate with the new structure, his followers followed his particular style. As his worship has not been purely religious, it has also been a center of practical education, so he expresses his mystical points and teaches a prophetic role, in addition to adapting mysticism to the appearance of the Shari'a, such as Abu Hamed Ghazali, trying to teach and guide. So he considered the task of repenting the sinners and executing the deed to be famous and forbidding vengeance and the destruction of the abyss as its inherent duty. As his worship has not been purely religious, it has also been a center of practical education, so he expresses his mystical points and teaches a prophetic role, in addition to adapting mysticism to the appearance of the Shari'a, such as Abu Hamed Ghazali, trying to teach and guide, so he considered the task of repenting the sinners and executing the deed to be famous and forbidding vengeance and the destruction of the abyss as its inherent duty.

Because he is a courageous and fearless freeman about the kings Oppression and his men, he has abandoned the silence and urges his audiences to fight against them.

But he nevertheless penetrated the Seljuk system and was able to solve the problems of his time by compromising with the rulers and political rulers, especially Sultan Sanjar, and drawing attention to his will. This devotion continued even after his death, causing some of them to erect beautiful buildings around his grave in order to protect their devotion. Another of his unique traits is that he does not claim to be a writer, a whistleblower, and a scientist. And says in this matter: "We do not dispute the words, we fight the principles of religion and knowledge". And in one of his writings on book and bookmaking he says: "Anyone who makes a book or writes something will realize that this ethnic talk is over and the ethnic will reject it, and if it does, they will suffer". His influential writings on Islamic mysticism, with an expressive and gifted language as an ancient document, survived. Still as a powerful gem in Iranian literature and culture, Ahmad Jam is a wonder of the vast mysticism whose compilation of old teachings is a mixture of teachings and spirituality, a marvelous finesse skill in a simple framework based on folk culture and language of the alley and market that is far from the soulless circles of literary properties of the soul and in a way that is more in tune with people and popular culture.

Another of his unique characteristics is the existence of his cultural and scientific family who after his death, in addition to having the position of Sheikh al-Islami and religious influence among the people, due to their close ties to the powerful monarchs (Al-Cret) who controlled Herat and its functions during the Ilkhani era, it further flourished and build the city of Torbat-e-Jamm, which was affected by climatic conditions, historical ups and downs, and various events thanks to the presence of Ahmad Jam, he turned from a simple village into a thriving city. 
Although a group of Sheikh's disciples have elevated him to the level of sanctity and attributed to him many tales and dignities, a group like al-Nasser al-Din has relied on the ignorant evidence of the scientific, religious and historical character of this mystic. But the training of students such as Hafiz Shirazi and Nur al-Din Abdul Rahman Jami and Sheikh Zeinuddin Abu Bakr Taibadi and... is the golden leaf that this great moral teacher holds. These are some of the most prominent features of Ahmad Jam, which is a summary of the greatness of this luminous old man in ancient Khorasan and modern-day Iran.

\section{References}

Fazel, Ali. (1989). Reports by Ahmad Jam Namaghi, Heidari Printing. Toos Publications, First Edition, Tehran.

Ghazali Tusi, Abu Hamed Imam Mohammad, Kimia Saadat. (2005). by the efforts of Hossein Khadiv Jam, published by the Scientific and Cultural Inscription Publishing Company, 12th Edition, Tehran.

Jam, Ahmad (zhende Peel), Knauzolahkamah, Researcher Dr. Ali Fazel. (2008). Corrected by Dr. Hassan Nasiri Jami, Publisher, Institute of Humanities and Cultural Studies, Farshiv Publishing, Tehran, First Edition.

Jam, Ahmad (Zhende Peel), Muftah El-Najat. (2000). Correction and Introduction by Dr. Ali Fazel, Publisher, Institute of Humanities and Cultural Studies, Farshiv Press, Tehran, Third Edition.

Jam, Ahmad (zhende Peel), Rozeh al-Mazinbin and Jenna al-Mushtaqin. (2008). Correction and Introduction by Dr. Ali Fazel, Publisher, Institute of Humanities and Cultural Studies, Farshiv Press, Tehran, Third Edition.

Jam, Ahmed (zhende Peel), Rouzah al-Mantbin and Jenna al-Mushtaqin. (2008). proofreading and introduction by Dr. Ali Fazel. Publisher of Humanities and Cultural Studies Research Institute. Farshiv Print, Tehran, Third Edition.

Jameh (Zhende Peel), Ahmad, Mohammad bin Motahar bin Shaykh al-Islam, Abul Fattah, Hadiqa Al-Haqiqah. (1343). by Dr. Mohammad Ali Movahed, under the supervision of Dr. Ehsan Yar Shater, Publisher of Book Publishing, Tehran.

Jameh, Ahmad (zhende Peel), Anas al-Taebin Saratollah Al-Mobin. (1990). Volume I, Coping with Five Editions and Correction and Introduction by Dr. Ali Fazel, Publisher of Iran Cultural Foundation, Tehran, Bita.

Kasravi, Ahmad, Sufism. (1323). Electronic Version, Second Edition.

Mastmali Bukhari. (1987). Abu Ibrahim Ismail bin Mohammad, An Introduction to Correction of Lamebih al-Tasuf, with Introduction and Correction and Mohammad Roshan, Asatir Publications, First Edition.

Seraj Toosi, Abounasr, al-Liam al-Fisouf, Reynold Allan Nixon. (2003). ranslation by Dr. Mehdi Mojtaba, Mythology First Edition. 